\title{
ANALISIS MIKROBIOLOGI JAJANAN MINUMAN DI SEKITAR SEKOLAH DASAR PADA WILAYAH JEMURWONOSARI, SURABAYA
}

\author{
Endah Prayekti \\ Universitas Nahdlatul Ulama Surabaya \\ endahphe@unusa.ac,id
}

\begin{abstract}
Snack as food and beverages, present vastly in Surabaya. Start from street vendor to famous stores. The distribution of these snacks trader often found in schools, from primary to high school. Common problems from these food dan baverages sales is their hygine. With a low sales price, other raised problem are the using of raws material for snack production which lead to hazard microbial contamination. This reaserch aim is to monitors the quality of beverages on microbiology that been sold in around primary school of Jemur Wonosari District, Surabaya. Two microbiology parameters that been analize were coliform bacterial and Escherichia coli number. Beverages sample that been used were 9 samples, then analize using most propable number using 15 tube series. The Results then analize descriptively. From 9 samples, all were exceed the standar quality according to Kepmenkes RI No.492/MENKES/PER/2010.
\end{abstract}

Keywords : Coliform, Escherichia coli, Beverages, Primary School

\section{PENDAHULUAN}

Jajanan baik berupa makanan maupun minuman, tersaji secara luas di Surabaya. Mulai tingkat pedagang kaki lima hingga di toko ternama. Sebaran pedagang jajanan ini kerap kali dijumpai di sekolah-sekolah, dari tingkat dasar hingga tinggi. Menjamurnya pedagang tak luput disebabkan banyaknya peminat. Beberapa hal yang mirip dijumpai di semua sekolah dasar adalah adanya pedagang kaki lima yang menjajakan makanan kecil dan minuman. Makanan dan minuman tersebut dijual dalam harga murah yang terjangkau oleh siswa dan siswi SD. Siswa SD yang terpapar oleh jajanan di sekolah dapat beresiko menderita diare bila jajanan tersebut tidak hiegienis. Ruchiyat (2007) menunjukkan adanya hubungan antara frekuensi konsumsi makanan jajanan dengan kejadian diare pada siswa kelas 4, 5 dan 6 SDN dalam studinya.

Studi tersebut juga menunjukkan bahwa siswa yang sering kali jajan diluar kantin sekolah lebih sering mengalami diare.

Salah satu parameter dari hieginitas jajanan dapat dilihat dari parameter mikrobiologinya. Keberadaan bakteri koliform dan E.coli dalam makanan merupakan indikator untuk menentukan tingkat kualitas makanan dan minuman secara mikrobiologi menurut Kepmenkes RI No.492/MENKES/PER/2010.

Mengingat harga yang murah,
kekhawatiran yang timbul adalah adanya
penggunaan bahan-bahan mentah yang
berpotensi adanya masuknya kontaminan
makanan ataupun minuman berupa
mikroorganisme yang berbahaya bagi tubuh.
Adanya mikroorganisme tersebut dapat
menyebabkan gangguan dalam pencernaan,
mulai diare hingga yang paling parah adalah


typus. Salah satu jenis jajanan yang cukup beresiko adalah dari jenis minuman. Marhamah dan Huda (2014) menemukan bahwa es sirup yang dijual di SD Negeri di Bandar Lampung memiliki kualitas yang kurang baik karena tidak memenuhi syarat Kemenkes RI. No. 492/MENKES/PER/IV/ 2010.

Data Dinkes Jawa Timur (2014) menunjukkan bahwa bahwa mulai tahun 2009 sampai dengan tahun 2014, capaian penemuan kasus diare cenderung meningkat setiap tahunnya. Untuk itu monitoring terhadap minuman perlu dilakukan untuk meminimalisir potensi diare pada anak-anak.

\section{METODOLOGI PENELITIAN}

\section{Jenis, Populasi, Sampel, dan Lokasi Penelitian}

Jenis penelitian ini merupakan penelitian deskriptif observasional. Penelitian dilakukan di Laboratorium Mikrobiologi, Kampus B, Universitas Nahdlatul Ulama Surabaya. Populasi yang dijangkau adalah penjual minuman disekitar Sekolah Dasar di wilayah Jemurwonosari, Surabaya. Sampel penelitian yang digunakan adalah 9 minuman yang dijual oleh pedagang dalam populasi.

\section{Prosedur Penelitian}

Metode analisis sampel menggunakan metode MPN dengan 15 seri tabung, menggunakan media Lactose Broth, Brillian Green Lactose Bile Broth dan Eosin Metilin Blue Agar. Metode MPN yang digunakan dalam penelitian ini secara rinci adalah sebagai berikut:

\section{Menghitung Jumlah Bakteri Koliform}

1. Menyiapkan 15 tabung yang berisi Lactosa broth (LB) steril dengan durham terbalik didalamnya. Tabung tersebut dibagi menjadi 3 kelompok. 5 tabung seri pertama, 5 tabung seri kedua, dan 5 tabung seri ketiga. Digunakan untuk uji penduga.
2. Menyiapkan 15 tabung yang berisi Brilliant Green Lactose Broth (BGLB) steril dengan durham terbalik didalamnya. Tabung tersebut dibagi menjadi 3 kelompok. 5 tabung seri pertama, 5 tabung seri kedua, dan 5 tabung seri ketiga. Digunakan untuk uji penegas.

3. Untuk uji penduga, dilakukan dengan memasukkan sampel menggunakan pipet ke dalam 5 tabung seri pertama LB sebanyak $10 \mathrm{ml}, 5$ tabung seri kedua LB sebanyak $1 \mathrm{ml}$, dan 5 tabung seri ketiga LB sebanyak $0,1 \mathrm{ml}$.

4. Media yang telah diberi sampel kemudian diinkubasi pada suhu 350C, selama 24 jam. Hasil yang positif bila terdapat gelembung gas minimal $10 \%$ pada tabung durham. Bila tidak dijumpai, inkubasi dilanjutkan 24 jam pada suhu 350C.

5. Hasil yang positif setelah inkubasi maksimal pada 48 jam, kemudian dilanjutkan ke uji penegas.

6. Uji penegas dilakukan dengan mengambil 1-2 ose media pada tabung LB yang positif dan dimasukkan secara aseptik pada media BGLB.

7. Inkubasi media BGLB pada $350 \mathrm{C}$ selama 24 jam. Hasil yang positif bila terdapat gelembung gas minimal $10 \%$ pada tabung durham.

8. Kombinasi hasil tabung yang positif pada media BGLB kemudian dicocokkan ke dalam tabel MPN seri 15 tabung (5-5-5).

9. Jika seri tabung positif tidak dijumpai dalam tabel MPN, maka jumlah bakteri koliform dihitung menggunakan rumus berikut ini (Waluyo, 2010):

$$
\mathrm{MPN} / 100 \mathrm{ml}=\frac{A x 100}{\sqrt{B x C}}
$$

Keterangan :
A : Jumlah tabung yang menunjukkan hasil positif
B : Jumlah sampel yang menunjukkan hasil negatif (ml)
C : Jumlah total sampel yang diujikan 
$(\mathrm{ml})$

\section{Menghitung jumlah Bakteri Escherichia coli}

1. Hasil positif pada tabung BGLB kemudian dilanjutkan ke medium EMB dengan cara streak menggunakan ose.

2. Menginkubasi bakteri pada media EMB selama 24 jam pada suhu $37^{\circ} \mathrm{C}$.

3. Mengamati hasil streak pada media EMB. Hasil posif ditandai dengan adanya koloni hijau metalik pada media EMB.

4. Mengkombinasi hasil positif pada media EMB yang diperoleh kemudian dicocokkan dengan tabel MPN seri 15 tabung (Fardiaz, 1993).

\section{HASIL DAN PEMBAHASAN}

Hasil

Sampel minuman yang dianalisis meliputi minuman yang dijual di sekitar Sekolah Dasar di wilayah Kelurahan Jemur Wonosari, Kecamatan Wonocolo. Sampel minuman yang diambil meliputi es teh instan, es rasa buah instan, es krim, dan es cincau. Total jumlah sampel yang dianalisis adalah sebesar 9 sampel. Sampel yang didapat kemudian dianalisis jumlah bakteri koliform dan Escherichia coli. Adapun hasil penelitian ini tersaji pada tabel 1.

Tabel 1. Jumlah Bakteri Koliform dan E.coli dari sampel minuman

\begin{tabular}{ccc}
\hline $\begin{array}{c}\text { Sampel } \\
\text { No }\end{array}$ & $\begin{array}{c}\text { Jumlah Bakteri Koliform } \\
(\text { sel/100ml) }\end{array}$ & $\begin{array}{c}\text { Jumlah Bakteri E.coli } \\
(\text { sel/100ml) }\end{array}$ \\
\hline 1 & 49 & 33 \\
2 & 16,8 & 9 \\
3 & $>1600$ & 17 \\
4 & 29,4 & 9 \\
5 & 23,4 & 4 \\
6 & 1600 & 34 \\
7 & $>1600$ & 9 \\
8 & 19,1 & 4 \\
9 & 80,5 & 17 \\
\hline
\end{tabular}

\section{Pembahasan}

Pemeriksaan cemaran mikroba pada bahan pangan baik itu makanan maupun minuman kerap kali dilakukan. Hasil yang didapatkan pun banyak dijumpai adanya bahan pangan yang berada di atas ambang batas standar cemaran mikroba dalam makanan maupun minuman (Nisa et al., 2012; Puspitasari, 2013; Ritonga et al., 2014; Aditya dan Muthiadin, 2015; Fathimah et al., 2017). Dalam penelitian ini, analisis sampel secara mikrobiologi dengan menghitung jumlah bakteri koliform dan E.coli menunjukkan hal yang serupa, yaitu dijumpai kedua bakteri tersebut (Tabel 1). Berdasarkan temuan tersebut, tentunya dapat dibaca bahwa tidak banyak penjual yang memperhatikan akan hieginitas dari produk yang dia jual.
Secara umum, hasil bakteri koliformnya dan E.coli diluar ambang batas maksimal yang diperbolehkan dalam air yang diminum. Menurut Kepmenkes RI No.492/MENKES/ PER/2010 tentang persyaratan kualitas air minum, menyebutkan bahwa jumlah bakteri koliform dan bakteri Escherichia coli dalam air minum adalah 0 . Sehingga dapat dikatakan bahwa minuman yang diambil sebagai sampel tidak memenuhi syarat untuk dikonsumsi. Jumlah bakteri koliform dalam sampel minuman yang diujikan sangatlah beragam nilainya, dari mulai yang terendah dijumpai pada sampel 6 hingga yang tertinggi dijumpai pada sampel 3, 6, dan 7 .

Begitu pula dengan jumlah bakteri Escherichia coli dalam sampel minuman yang diujikan memiliki hasil yang bervariasi. Jumlah terendah didapatkan pada sampel 5 dan 
8, sedangkan tertinggi diperoleh pada sampel

6. Seluruh minuman yang diuji adalah minuman yang menggunakan es batu. Cemaran mikroba dalam minuman yang dijual dapat berasal dari berbagai sumber. Beberapa diantaranya yaitu berasal dari es batu (Hadi et al., 2014), air, proses pembuatan yang tidak higienis, dan peralatan yang digunakan tercemar bakteri (Wibawa, 2008). Berdasarkan kemungkinan ini, maka pedagang perlu memperhatikan sumber air yang digunakan, memilih es batu dari air yang telah dimasak, menggunakan peralatan bersih serta memperhatikan kebersihan diri dan lingkungan dalam proses pembuatan. Beberapa hal yang dapat mempengaruhi kualitas minuman adalah bahan baku, pengolahan, letak dari sumber berpotensi penyakit, dan cara penangan minuman hingga penyajian (Ritonga et al., 2014).

\section{KESIMPULAN}

Semua minuman yang diujikan memiliki jumlah bakteri koliform dan Escherichia coli di luar ambang batas berdasarkan Kepmenkes RI No.492/MENKES/PER/2010 tentang persyarat an kualitas air minum.

\section{UCAPAN TERIMAKASIH}

Terima kasih kepada mahasiswa D-IV Analis Kesehatan UNUSA dan asisten laboratorium Kampus B Universitas Nahdlatul Ulama Surabaya yang telah membantu dalam penyelesaian penelitian ini.

\section{DAFTAR PUSTAKA}

Aditia, L., dan Muthiadin, C. 2015. Uji Kualitas Mikrobiologis Pada Makanan Jajanan di Kampus II Universitas Islam Negeri (UIN) Alauddin Makassar. Biogenesis. Vol 3, No. 2.

Dinkes. 2014. Profil Kesehatan Jawa Timur 2014. Dinas Kesehatan Provinsi Jatim.

Fardiaz, S. 1993. Analisis Mikrobiologi Pangan. Raja Grafindo Persada. Jakarta.
Fatimah, S., Prasetyaningsih, Y., dan Sari, M.F.I. 2017. Analisis Coliform Pada Minuman Es Dawet Yang Dijual Di Malioboro Yogyakarta. Prosiding Seminar Nasional IKAKESMADA. ISBN: 978-979-3812-41-0. 75-80.

Hadi, B., Bahar, E., dan Semiarti, R. 2014. Uji Bakteriologis Es Batu Rumah Tangga yang digunakan Penjual Minuman di Pasar Lubuk Buaya Kota Padang. Jurnal Kesehatan Andalas. 3 (2).

Kepmenkes RI No.492/MENKES/PER/2010 tentang PERSYARATAN KUALITAS AIR MINUM.

Nisa, A.S., Hastuti, U.S., Witjoro, A. 2012. Analisis Mikrobiologi Minuman Teh Seduhan Berbeda Merk Berdasarkan Nilai MPN Coliform Di Kota Malang. Prosiding Seminar Biologi Vol 9, No 1. Seminar Nasional IX Pendidikan Biologi. Publisher: Prodi Pendidikan Biologi FKIP UNS. 518-523.

Marhamah dan Huda, M. 2014. Kualitas Mikrobiologi Minuman Jajanan (Es Sirup) Pada Kantin SD Negeri Di Wilayah Kota Bandar Lampung. Jurnal Analis Kesehatan. Vol 3, No.1.

Ritonga, R, Marsaulina, I, dan Chahaya, I. 2014. Analisis Escherichia coli Dan Higiene Sanitasi Pada Minuman Es Teh Yang Dijual Di Pajak Karona Jamin Ginting Kecamatan Medan Baru Tahun 2013. Jurnal Lingkungan dan Kesehatan Kerja. Vol 3, No 2.

Ruchiyat, A. 2007. Hubungan antara Hygine Perorangan, Frekuensi Konsumsi, Dan Sumber Makanan Jajanan Dengan Kejadian Diare. Naskah Publikasi Skripsi. Fakultas Kedokteran. Universitas Gadjah Mada. Yogyakarta.

Waluyo, L. 2010. Teknik dan Metode Dasar Mikrobiologi. Malang UMM Press.

Wibawa, A. 2008. Faktor Penentu Kontaminasi Bakteriologik pada Makanan Jajanan di Sekolah Dasar. 
Jurnal SainHealth Vol. 1 No. 2 Edisi September 2017

(C) Fakultas Ilmu Kesehatan Universitas Maarif Hasyim Latif Sidoarjo

p-ISSN : 2548-8333

e-ISSN : 2549-2586

Jurnal Kesehatan Masyarakat Nasional. Vol. 3, No. 1.
Indonesia Seri Sains Dan Teknologi. Vol. 2, No.1

Puspitasari, R.L. 2013. Kualitas Jajanan Siswa

di Sekolah Dasar. Jurnal Al-Azhar 